\title{
Hexactins in the 'protomonaxonid' sponge Choiaella and proposal of Ascospongiae (class nov.) as a formal replacement for the Protomonaxonida
}

\author{
JOSEPH P. BOTTING
}

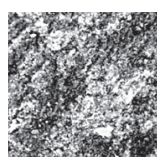

\begin{abstract}
The protomonaxonid sponges are a controversial early group with supposed ties to the demosponges, but the group also possesses features that imply a much earlier-branching position in sponge evolution. A new species, Choiaella hexactinophora sp. nov., shows a typical protomonaxonid body plan but also contains small hexactin-based spicules, a skeletal element today restricted to the class Hexactinellida, but which has been proposed to be plesiomorphic for Porifera and lost in the other living classes. This finding from the Castle Bank fauna (Middle Ordovician of the Builth Inlier, Wales, UK) confirms continuity of the protomonaxonid lineage, as hexactins are also known from fossils interpreted to be among the earliest members of the group. The presence of hexactins effectively rules out a demosponge affinity, and supports previous interpretations requiring the protomonaxonids to be treated as an earlybranching sponge clade rather than assigning them to an extant class. To facilitate this, this paper proposes a formal replacement of the majority of the group as the Ascospongiae nov., an extinct class within Porifera. - Key words: Porifera, Cambrian, evolution, protomonaxonid, Choiaella, sponge.
\end{abstract}

Botting, J.P. 2021. Hexactins in the 'protomonaxonid' sponge Choiaella and proposal of Ascospongiae (class nov.) as a formal replacement for the Protomonaxonida. Bulletin of Geosciences 96(3), 265-277 (5 figures). Czech Geological Survey, Prague. ISSN 1214-1119. Manuscript received November 22, 2020; accepted in revised form May 19, 2021; published online June 6, 2021; issued July 4, 2021.

Joseph P. Botting, Department of Natural Sciences, Amgueddfa Cymru-National Museum Wales, Cathays Park, Cardiff CF10 3NP, UK \& Nanjing Institute of Geology and Palaeontology, Chinese Academy of Sciences, 39 East Beijing Road, Nanjing 210008, China; acutipuerilis@yahoo.co.uk

The interpretation of early fossil sponges is crucial for our understanding of the evolutionary history and morphology of early animals. Specifically, the nature and affinities of the major groups of Cambrian sponges (including protomonaxonids, reticulosans and heteractinids) are both contentious and pivotal for reconstructing the likely morphology and structure of the poriferan stem group (Botting \& Muir 2018). Until recently, these groups have largely been regarded as belonging to crown- or stem-group lineages of the demosponges, hexactinellids and calcareans, respectively (Finks et al. 2004), and it was thought that the common ancestor of these classes predated the origin of spicules, which were independently evolved in each lineage (Reitner \& Mehl 1996, Murdock 2020). The stem group of sponges as a whole was therefore thought to have had a much deeper history, extending back into the Precambrian but as presumed soft-bodied animals with little chance of fossilisation. In this way, the fossil record could be considered compatible with predictions made by molecular clocks (e.g. Cunningham et al. 2017, Dohrmann \& Wörheide 2017) and supposed biomarkers (e.g. Zumberge et al. 2018, but the veracity of these data have now been considerably undermined: Nettersheim et al. 2019).
Tang et al. (2019) suggested, based on some early sponge fossils with organic layers within the spicules, that organic precursors of spicules may have been shared across sponges, but became biomineralised independently in each lineage (a scenario also preferred by Murdock 2020). However, this hypothesis does not take into account the appearance of many early sponge fossils with anomalous character combinations, which can be combined into an alternative interpretation (Botting \& Muir 2018) that the Cambrian sponge fossil record consists dominantly of taxa that diverged before the class crown groups, including likely candidates for the poriferan stem group. These taxa, which display traits such as tetraradial symmetry and biminerallic (silica plus calcite) spicules that are not present in living sponges, can only easily be accommodated by a shared, biomineralised spicule ancestry (Botting \& Muir 2018). Distinguishing between these possibilities will depend on additional descriptions and interpretations of early sponge fossils; the scenario of Botting \& Muir (2018) predicts increasing intergradation of the (biomineralised) Cambrian sponge fossil record, whereas Tang et al.'s (2019) hypothesis implies that the deepest nodes in sponge evolution will remain obscure 
without very unusual preservation of entirely soft-bodied animals.

Among early sponge groups, the protomonaxonids (Finks \& Rigby 2004) have been widely regarded as demosponges (Walcott 1920, Rigby 1986, Reitner \& Wörheide 2002, Rigby \& Collins 2004, García-Bellido et al. 2007, Clites et al. 2012, Wu et al. 2014), but without any basis in shared characters beyond the dominant spicules being monaxons. Even these spicules are far larger in most protomonaxonids than in virtually all living demosponges, and show a very different arrangement in a different body form. A few taxa such as Hazelia Walcott, 1920 that were included within the group by Finks \& Rigby (2004) do, however, show clear demosponge characteristics, and are entirely distinct from the architecture of the larger-spiculed sponges. Botting et al. (2013) separated the protomonaxonids into two groups on this basis: their 'Group 1' constitute the bulk of the protomonaxonids, including the dominant range of discoidal, conical or subcylindrical taxa (with radial symmetry) with large monaxons that are oriented primarily longitudinally in a thin body wall. In some cases, the spicules are highly modified, with open bases and a thick organic outer layer (Botting et al. 2013). This group includes Lenica Goryanskii, 1977, which was shown by Botting et al. (2012) to have possessed spicules composed of both silica and a different mineral that was almost certainly calcium carbonate. Botting et al. (2013) also reinterpreted the putative hexactinellid root tuft Hyalosinica Mehl \& Reitner, 1993 in Steiner et al. (1993) as a basal protomonaxonid, together with several unnamed taxa that showed a similar combination of a tall, cylindrical skeletal wall composed dominantly of sublongitudinal monaxons with small, short-rayed hexactins. The leptomitid protomonaxonid Heteractenigma Botting \& Zhang, 2013 also possessed anomalous (and tiny) hexactine, triactine and pentaradiate spicules in addition to the typical diactin-based skeleton. These anomalous characters are sufficient to generate a widespread (though not yet universal) acceptance that protomonaxonids such as Lenica must be considered as a distinct group rather than as demosponges (e.g. Cong et al. 2018, Tang et al. 2019, Wang et al. 2019), or at least that they need to be carefully reconsidered (Murdock 2020).

To avoid the implication that protomonaxonids represent an early-branching group that were very distinct from all living classes, it may be argued that the tall, hexactin-bearing protomonaxonids interpreted as basal are a separate group (perhaps of hexactinellid origin; de Laubenfels 1955, Reitner \& Mehl 1996) from the more typical taxa such as Choia, Hamptonia, and many others (Rigby \& Collins 2004) that have a flatter morphology with apparently radiating spicules (actually longitudinal in a flattened body form) and could potentially be more easily assigned to demosponges. This possibility would be excluded by the existence of hexactins reported from a species of Choiaella from the Fezouata Biota of Morocco (Botting et al. 2013, Botting 2016), but the material is in a private collection and therefore has not been illustrated or fully described. In this paper, I describe similar, small hexactins in a Middle Ordovician species of Choiaella from Castle Bank (Wales, UK), demonstrating that hexactins were not restricted to the taxa regarded by Botting et al. (2013) as being basal protomonaxonids, but confirming that this group forms a continuum with more typical Cambrian lineages such as the Hamptoniidae and Halichondritidae. This discovery should refute any remaining suggestions that any of the Group 1 protomonaxonids of Botting et al. (2013) were demosponges. Furthermore, the range of anomalous character combinations in these early sponges reiterates that protomonaxonids can only plausibly be interpreted as an extinct, early-branching sponge group, and this is formalised herein.

\section{Geological Background}

The material comes from an extensive new sponge fauna in a small quarry locality known as Castle Bank, near Llandrindod (Wales, UK; Fig. 1), within the Middle to Late Ordovician volcanic island complex of the Builth Inlier (Davies et al. 1997, Botting \& Muir 2008). The fauna was recorded as a preliminary list within the Builth Inlier sponge palaeocommunity study of Muir \& Botting (2015), who noted that it was an unusual, protomonaxoniddominated fauna from an intermediate water depth (around storm wave base). Extensive further collecting has revealed a very diverse assemblage that includes numerous hexactinellid or reticulosan (plesiomorphic hexactin-bearing taxa; Botting \& Muir 2018) sponges in addition to the more common protomonaxonids.

The fauna is Middle Ordovician (Darriwilian) in age, from the middle to upper part of the Didymograptus murchisoni Biozone (Fig. 1). This level corresponds to the upper part of the Gilwern Volcanic Formation of Davies et al. (1997), which constitutes the bulk of the Builth Volcanic Group (including most of the erosion products of the local volcanic island, combined with ongoing smaller eruptive deposits). The sequence at Castle Bank consists of a ten-metre-thick succession of interbedded siltstone and pyroclastic volcanic deposits. The ash layers range from millimetric laminae up to a complex deposit 2-3 metres thick, but as with most of the upper part of the formation within the northern part of the inlier, the lithology is dominated by siltstone. Volcanic influences resulted in locally high sedimentation rates and rapid burial of intact organisms, as described for the slightly younger (lower 

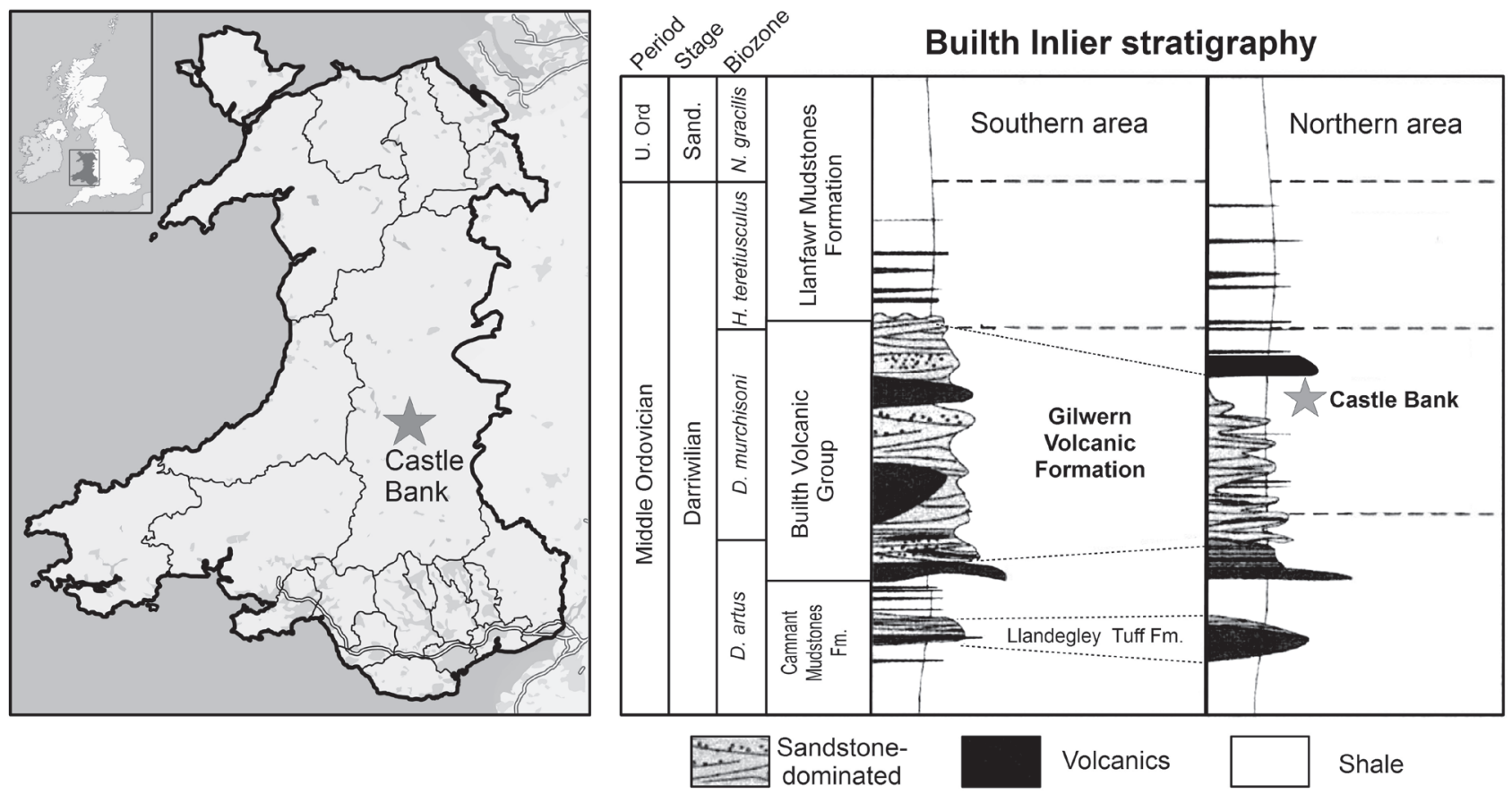

Figure 1. Stratigraphy and generalised location of the Castle Bank locality (Wales, UK). Lithostratigraphy is complex (especially for the Builth Volcanic Group), and not all formations are included; see Davies et al. (1997) for full details. Precise locality information is deposited with the specimens.

Hustedograptus teretiusculus Biozone) Holothurian Bed (Botting \& Muir 2013). Articulated sponge fossils occur at numerous sites within the overlying Llanfawr Mudstones Formation (Botting et al. 2011, Muir \& Botting 2015).

Spicules in sponges at this site are preserved either as moulds within dark brown, probably carbonaceous material (weathering paler), or as brown, probably ironoxide replacements that are presumed to be secondary after pyrite. At some levels with indurated sediment, spicules are still pyritised. Soft tissues are frequently visible as similar brown impressions, often obscuring the spicules; only in rare cases are the spicule impressions sharp and detailed.

Because of the vulnerability of the site and at the landowners' request, precise locality information is deposited with the specimens and is available to researchers.

\section{Material and methods}

Specimens are deposited in the National Museum Wales (Cardiff, UK), under accession number prefix NMW. The material was imaged with a Leica S8 APO stereomicroscope combined with a HiChromeAF MET camera, and optical contrast was manipulated via a cross-polarising ring light. Images were finally processed (contrast adjustment) using GXCapture and Open Office.

\section{Systematic palaeontology}

Phylum Porifera Grant, 1836

Class Ascospongiae nov.

Etymology. - From Greek ascos, meaning a bag or wineskin. This is the same root as for ascon, relating to the simplest aquiferous system architecture in living sponges.

Diagnosis. - Thin-walled sponges with radial symmetry, usually solitary (rarely branched in derived taxa); from discoidal to conical (lacking a narrowed osculum), bowlshaped or subcylindrical (in some taxa with osculum somewhat narrowed). Skeleton dominantly composed of long monaxon spicules, arranged primarily sub-longitudinally within the body wall (giving a radial appearance in flat conical sponges) or with plumose array; in later taxa, spicules may project strongly from the surface as prostalia. Spicules may be open-based and partly hollow in derived groups, with prominent organic sheath externally. Monaxon skeleton supplemented in some taxa by small hexactin-based spicules in scattered arrangement. Microscleres unknown and probably absent. Soft tissue wall appears to have been very thin, and lacking large internal canals or cavities.

Remarks. - This class is a proposed formal replacement for part of the Protomonaxonida Finks \& Rigby, 2004, 
which was defined as an order within the Demospongiae, but with serious problems in its definition and composition. The paraphyletic and polyphyletic status of the Protomonaxonida was discussed by Botting et al. (2013), with the recommendation that the term should not be used in a formal taxonomic context, although "protomonaxonid" could remain useful as a descriptive term. Included here are Botting et al.'s (2013) Group 1 protomonaxonids; their Group 2 protomonaxonids are considered to be Demospongiae.

It would be possible to redefine the scope of the group and retain Finks \& Rigby's (2004) name, but there are additional problems. Originally placed within the Clavaxinellida Lévi, 1956 (which is partly synonymous with the currently recognised Order Halichondrida Gray, 1867; see Van Soest \& Hooper 2002), the diagnosis was provided as: "Fibrous skeleton composed of oxeas alone" (Finks \& Rigby 2004, p. 9). This diagnosis is not only incorrect for the great majority of genera that they included (only Hazelia could reasonably be described as having a fibrous skeleton), it also does not distinguish the group from any living demosponges within the Halichondrida, which are characterised by bundled monaxon skeletons with the spicules bound together by various quantities of spongin to create fibres (Van Soest \& Hooper 2002). The previous definition is therefore not specific enough to identify a particular group, and yet was erected to encompass widely divergent taxa that do not fall within even the vague diagnosis. Retaining this name while changing the definition and scope would be confusing, due to the connotations of its previous usage, and I therefore prefer to redefine the concept entirely.

Although the new class contains a diversity of forms and skeletal structures, the diagnosis provided gives a clear separation from all other taxa. Hexactinellids with a monaxon-dominated skeleton such as certain Rossellidae (Tabachnick 2002) show an entirely different skeletal arrangement, and much thicker walls that allow a far more complex aquiferous system. Monaxonid demosponges differ in possessing far smaller spicules (usually by at least one order of magnitude), arranged in a much more complex architecture, together with a thick body wall with a complex internal canal system.

One aspect not considered in the diagnosis is that of mineralogy; in at least some taxa (Botting et al. 2012), spicules were biminerallic, composed of both a silica core (around an axial filament) and an outer layer of probably calcite. Information on primary mineralogy of these spicules is difficult to obtain from fossils, and more studies are needed to assess how widespread the feature is, although it is reasonable to suspect homology with other biminerallic early sponges such as Eiffelia (Botting $\&$ Muir 2018). These is also potentially morphological continuity with other early sponges, as Botting \& Muir
(2018) speculated that the group was derived from the distinctive reticulosan genus Diagoniella through multiplication of the monaxial basalia and reduction of triaxons (structural similarities between the groups also being noted by Dzik 2002). If this suggestion is true, then additional intermediate fossil taxa would be expected, and at that point the diagnosis and scope of the class can be modified to incorporate them.

Taxa included. - The following families (as compiled by Finks \& Rigby 2004, with additions) are included within the new class definition, although some specific genera assigned by them are excluded: Leptomitidae de Laubenfels, 1955; Hamptoniidae de Laubenfels, 1955; Ulospongiellidae Rigby \& Collins, 2004; Choiidae de Laubenfels, 1955; Wapkiidae de Laubenfels, 1955; Halichondritidae Rigby 1986; Piraniidae de Laubenfels, 1955 (excluding Moleculospina Walcott, 1920; see Botting et al. 2019) and Musaspongiidae Jell \& Cook, 2011. Of these, the Choiidae and Hamptoniidae overlap considerably, and should probably be conflated (see Botting et al. 2013). Also included is Hyalosinica Mehl \& Reitner, 1993 in Steiner et al. (1993) (together with additional, unnamed taxa described by Botting et al. 2013 as 'basal protomonaxonids'); the genus is not currently assigned to a family. Saetaspongia Mehl \& Reitner in Steiner et al., 1993 (see Botting \& Peel 2016) is also placed within the Ascospongiae, with family uncertain.

\section{Family uncertain}

Discussion. - The simple morphology of Choiaella makes placement at family level within the ascosponge lineage difficult, especially with the lack of a formal classification of the basal groups. Although traditionally assigned to the Choiidae (Finks \& Rigby 2004), this placement is not well supported, as it is based on only two very widespread (within the group) and convergence-prone characters: longitudinal monaxon spicules and a flattened, open conical to discoidal morphology. The recognition of hexactine spicules in Choiaella herein makes a relationship to the basal ascosponges more compelling, and therefore at this stage the family affiliation is left open.

\section{Genus Choiaella Rigby \& Hou, 1995}

Type species. - C. radiata Rigby \& Hou, 1995.

Diagnosis (emended after Rigby \& Hou 1995). - Small discoidal to low, broad, obconical sponges with skeleton composed of longitudinal thatch of small monaxons, probably oxeas, generally in one continuous size range. Spicules may be locally bundled but do not extend beyond edge of disc other than as minor fringe; lacks major coarse 

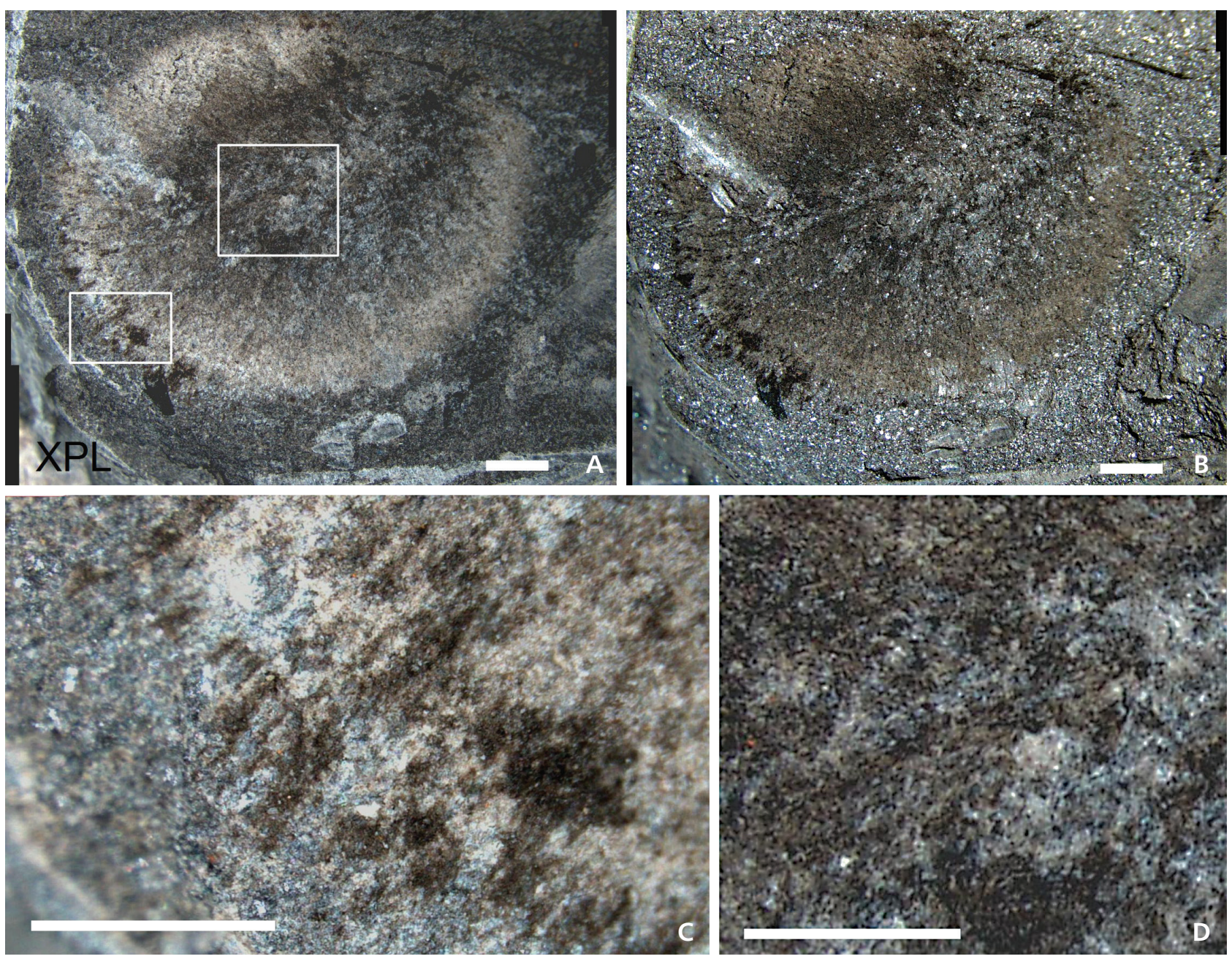

Figure 2. Holotype of Choiaella hexactinophora sp. nov., NMW.2021.3G.1. A - overall view in cross-polarised light; B - overall view in planepolarised light; $\mathrm{C}$ - marginal area showing dense thatch of monaxial spicules with irregular projections of larger spicules at margin; D - magnification of central area in A, showing more open fabric and irregular bundles of monaxons. Scale bars $1 \mathrm{~mm}$.

coronal spicules. Some species (at least) contain small hexactin-based spicules within the skeletal disc.

Discussion. - The addition of a new spicule type to the diagnosis may be considered to be sufficient to erect a new genus instead of expanding the genus definition. In this case, however, there is a strong likelihood of the additional hexactins having been either overlooked or not preserved, due to their small size. As a result, and because of the otherwise close similarity to the morphology of the type species, the preferred approach is to modify the understanding of the existing genus.

Species included. - C. ovata Yang, Zhao \& Wu, 2003; C. scotica Beresi, Botting \& Clarkson, 2010; C. hexactinophora sp. nov.

Occurrence. - The genus is known from the early Cambrian Sirius Passet Biota of Greenland and the Chengjiang and
Niutitang biotas of South China, the Early Ordovician Fezouata Biota of Morocco, Middle Ordovician rocks of Wales (herein), the Upper Ordovician strata of Wallace's Cast, Scotland (Laurentia), and the early Silurian Fentou Biota of South China (Zong et al. 2017). This distribution indicates a near-global spread during the Cambrian to early Silurian, and, as individual Choiaella specimens can be difficult to describe taxonomically, it is likely that they are present much more widely. The survival of the lineage into the Mesozoic (Neochoiaella Keupp \& Schweigert 2012 from the Jurassic Solnhofen Limestone) suggests that the apparent disappearance of the group after the early Palaeozoic may be a taphonomic artefact.

\section{Choiaella hexactinophora sp. nov.}

Figures 2, 3, 4

Types. - Holotype: NMW.2021.3G.1, an almost complete specimen lacking counterpart. 
Paratypes: NMW.2021.3G.2 and NMW.2021.3G.3, two complete but less-well-preserved specimens, with counterparts.

Type horizon and locality. - Middle Ordovician (Darriwilian; Didymograptus murchisoni Biozone) of Castle Bank, in the Builth-Llandrindod Inlier, central Wales. The site falls into the upper part of the Gilwern Volcanic Formation.

Material. - Types only.

Etymology. - From Greek, meaning hexactin-bearing.

Diagnosis. - Flat, slightly ovoid and fine-spiculed Choiaella with somewhat ragged margin due to slight, irregular projection of radial monaxons; radial fabric becomes irregular and more bundled (surrounding less heavily skeletonised regions) near the centre; numerous small hexactins concentrated primarily in central part of disc.

Description. - The majority of the information is obtained from the holotype (which preserves the finest skeletal detail), and details refer to that specimen unless stated. However, sufficient features are seen in each paratype to confirm the assignment to the same species, including the presence of triaxons.

Holotype (Figs 2,3) is vertically flattened, and partly weathered. Subcircular impression $9.5 \mathrm{~mm}$ by $8.5 \mathrm{~mm}$ (the smaller dimension possibly reduced slightly by rock breakage), with centre (from which spicules radiate) slightly off-centre; this is unlikely to be due to off-vertical compression of a conical body form, as there is no radial splitting. Paratypes (Fig. 4) are $7.5 \mathrm{~mm}$ by $5.5 \mathrm{~mm}$, and 5.5 by $4.5 \mathrm{~mm}$. Fabric is uniformly and densely radial in outer part of sponge, but in central part (Fig. 2D) is more irregularly plumo-reticulate, with denser sub-radial bundles surrounding apparent spaces or less densely skeletal regions. Colouring is paler (more weathered) in outer part of impression, implying that increasing spacing of skeletal fabric towards centre is genuine rather than a function of weathering.

Radial spicules weakly preserved, but are a maximum of $0.05 \mathrm{~mm}$ wide and more than $2 \mathrm{~mm}$ long (possibly to entire radius, but cannot be confirmed); most are much finer, forming a dense, continuous thatch. Spicules are entirely radial in orientation, but with some deviation that may be related to deformation on flattening; prominent radiating ridges do not appear to be discrete spicules or spicule bundles, but may indicate the presence of large, but obscured or weakly preserved spicules. Some larger monaxons project to a small but variable degree beyond the body wall margin, leading to a ragged appearance.
A substantial number of small cross-shaped spicules (either hexactins or derivatives such as stauractins) are present, most clearly visible within the central part of the skeleton (Figs 3; 4B, E); perpendicular rays are suggested by dark spots in the centres of some spicules (e.g. Fig. $3 \mathrm{~A}, \mathrm{~B})$, but cannot be definitely confirmed due to the small size. In some cases (Fig. 3A), rays appear to be nonorthogonal, but this may be due to oblique compression; the majority of rays are broadly at right angles. Typical ray length is up to $0.1 \mathrm{~mm}$ and usually $0.02-0.03 \mathrm{~mm}$ wide, evenly tapered. In exceptional cases, hexactin ray length may be up to $0.3 \mathrm{~mm}$, with basal diameter approaching $0.1 \mathrm{~mm}$; smaller spicules also occur (resolved down to ray length $0.05 \mathrm{~mm}$; Fig. $3 \mathrm{C}$ ) and rays tend to be more slender in proportion to length. In general, these spicules appear optically darker and have relatively higher physical relief compared with surrounding radial monaxons, despite being smaller. There is no clear arrangement to the hexactins, and no distinct size orders; rather, they are densely scattered through the skeleton, between the radiating monaxons. Ray angles are often slightly nonorthogonal (Fig. 3E), and in rare cases approximate to triactins (Fig. 3A).

Hexactins also locally visible in outer part of sponge (Fig. 3F), but tend to be focused in darker patches that appear to represent a slightly different layer within the body wall; there may, therefore, be some distinction between monaxial and hexactinal skeletal layers, at least in the distal part of the sponge.

Remarks. - The presence of hexactins is unique among described Choiaella species, and is currently a sufficient character for diagnosis for the species. However, these spicules are extremely small, and it remains possible that they have been overlooked in descriptions of other taxa; comparisons are therefore made below with other described species, focusing on alternative characters.

Only three named species of Choiaella have previously been described. Of these, C. ovata Yang, Zhao \& Wu, 2003 tends to show a strongly asymmetric, ovoid outline, and C. scotica Beresi, Botting \& Clarkson has fewer, strikingly coarser spicules. The type species $C$. radiata Rigby \& Hou, 1995 is similar in size and is the closest to the new species in overall form. Skeletally, it cannot easily be separated from the specimen described here without reference to the hexactins, although the monaxon spicules of $C$. hexactinophora sp. nov. are coarser (up to $0.05 \mathrm{~mm}$ wide, as opposed to $0.02 \mathrm{~mm}$ ). The type species' skeleton is, however, less dense, so that individual radial spicules are more obvious, and the radial fabric extends to the centre of the sponge. Furthermore, the preservational quality is such that any significant hexactins should have been obvious to Rigby \& Hou (1995). 

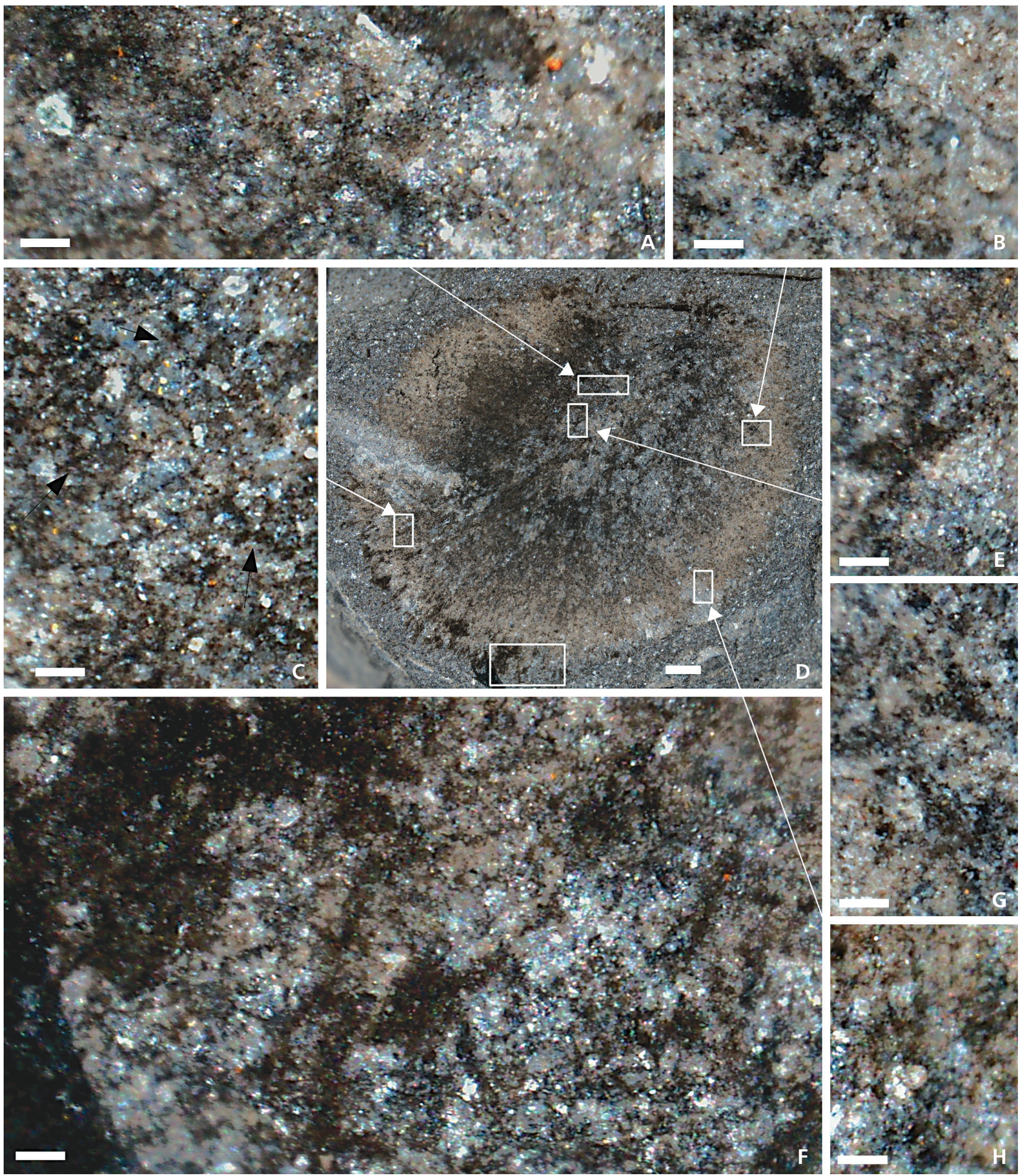

Figure 3. Details of holotype of Choiaella hexactinophora sp. nov., NMW.2021.3G.1, showing hexactins. A-C, E-H - magnifications of hexactins exposed in various parts of the sponge, with their positions on the overall sponge shown in D. Scale bars $1 \mathrm{~mm}$ in $\mathrm{D}, 0.1 \mathrm{~mm}$ in all other images.

Perhaps the closest similarity among described or illustrated material is to specimens referred to Choiaella sp. from the Lower Ordovician Fezouata Formation of Morocco (Botting 2016, fig. 3d). Most importantly, other specimens of Choiaella from the Fezouata Biota were mentioned by Botting et al. (2013) as containing small hexactins; however, as this material was in a private collection, it could not be illustrated or formally described. 

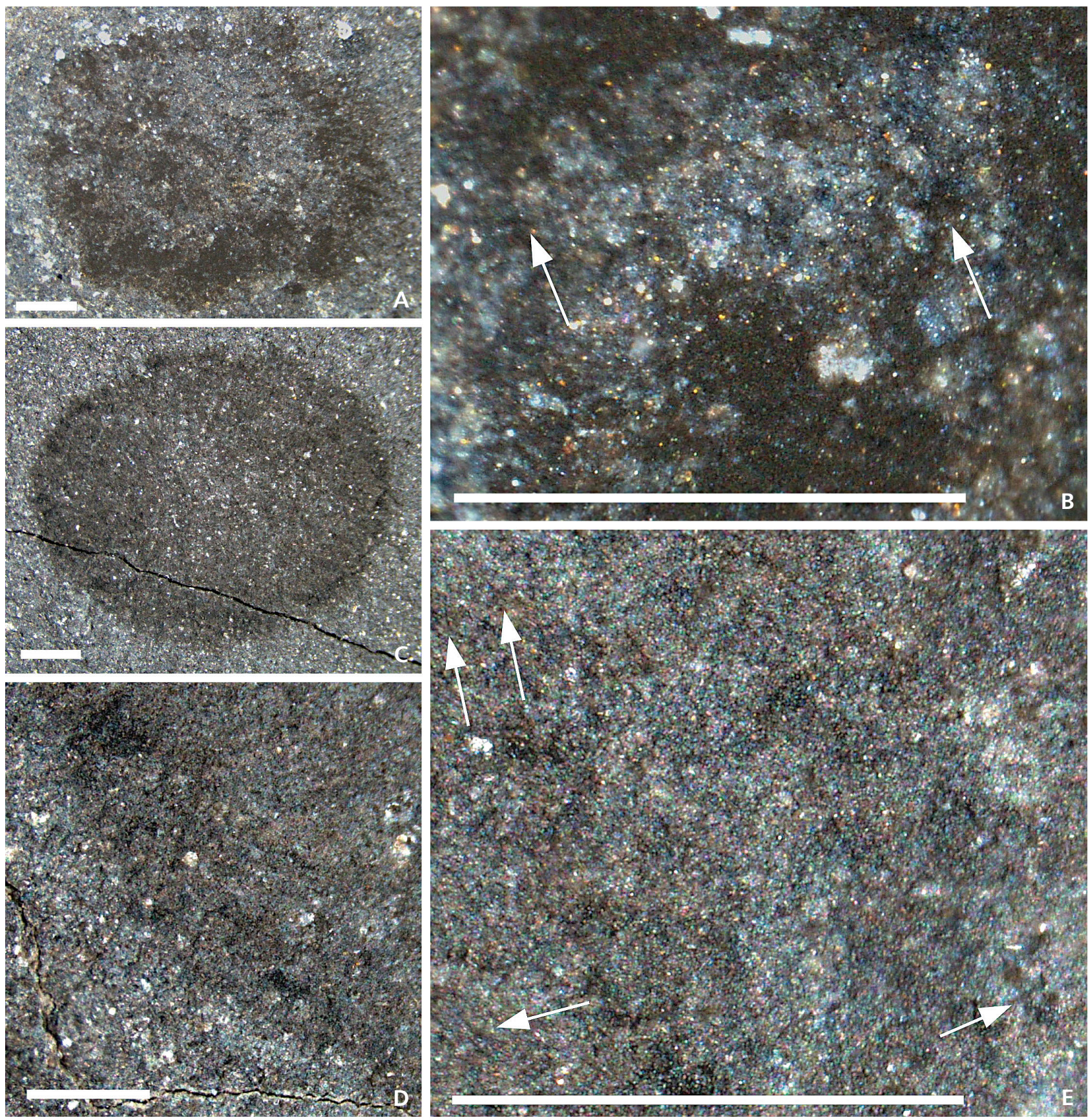

Figure 4. Paratypes of Choiaella hexactinophora sp. nov. A, B - NMW.2021.3G.2; A - overall view imaged under water and in partly cross-polarised light; B - detail of counterpart (wet, cross-polarised) showing small hexactins (examples arrowed); C-E - NMW.2021.3G.3; C - overall view in partly cross-polarised light; D - detail of margin (lower left in A) to show poorly preserved radial monaxons and marginal morphology; E - detail of central part of sponge, showing small hexactins (examples arrowed). Scale bars $1 \mathrm{~mm}$.

The presence of hexactins in the Castle Bank material confirms these observations. It is likely that the unnamed material from the Fezouata Biota is closely related to C. hexactinophora, and possible that it is conspecific.

A comparison should also be made with juvenile specimens of Hamptonia Walcott, 1920, which are extremely similar in form and probably very closely related
(Botting et al. 2013). Hamptonia tends to form a shallow bowl, with upturned edges, but the margin and radial spicule array are often rather irregular (Botting \& Peel 2016, Wang et al. 2019); it is also strictly defined on the presence of isolated, distinctly coarser spicules within the body wall, but these can be poorly developed and not obvious (e.g. Rigby 1986). In juvenile specimens, it is 
likely that the coarse spicules will be less obvious, and the outline more regular than in adults, such that distinguishing it from Choiaella becomes more difficult. No Hamptonia have yet been described with hexactins, however.

\section{Discussion}

The erection of a new class, even one that is long overdue, requires clear justification. In this case, the justification is that assignment of these sponges (both the new species, and the wider spectrum of protomonaxonids) to an existing class, either stem- or crown-group, is untenable, for reasons laid out below. The new findings strongly support continuity of the group as a coherent monophyletic clade, although it is plausible that this clade also includes the problematic chancelloriids (Botting \& Muir 2018, Botting et al. 2019). The inclusion of chancelloriids remains controversial at this stage, and only a slight modification of the diagnosis would be required to expand it to encompass them. Alternatively, it may in future be more utilitarian to adopt phylogenetic nomenclature rather than Linnean classification. Excluding (for now) the chancelloriids, there remain sufficient reasons to formalise the separation of these sponges from all living classes.

Choiaella is a typical member of the Ascospongiae (nov.), intermediate between the primitive condition (tall, subcylindrical, with short-rayed hexactins in an- cestral taxa) and the more derived, purely monaxonbased members of the lineage that include characters such as differentiation into larger prostalial spicules and open-based 'sclerites' with thick organic outer laminae (Botting et al. 2013, Botting \& Muir 2018). As such, the confirmation of hexactins in a new species is important for two reasons. Firstly, it supports the continuity of the evolutionary progression within the protomonaxonids outlined by Botting et al. (2013), tying the basal protomonaxonids (such as Hyalosinica) and leptomitids to the same major group as the more derived taxa such as Choia and Hamptonia, and confirming the full range of unique characters present in the group (Fig. 5). Secondly, the presence of hexactine-derived spicules in Choiaella supports the wider evolutionary scenario of Botting \& Muir (2018) that postulates the primitive status of hexactins, and is inconsistent with the traditional view (Reitner \& Wörheide 2002, Finks \& Rigby 2004) that protomonaxonids were simply early demosponges.

The new species further undermines the traditional evolutionary scenario that spicules evolved separately in each class, and that protomonaxonids are demosponges, because maintaining this view requires us to undermine the justification for it. This is because it demands convergence of the hexactine spicule morphology, when the uniqueness of that spicule morphology in modern sponges is the primary basis for the traditional assumption of independent spicule origins in hexactinellids and

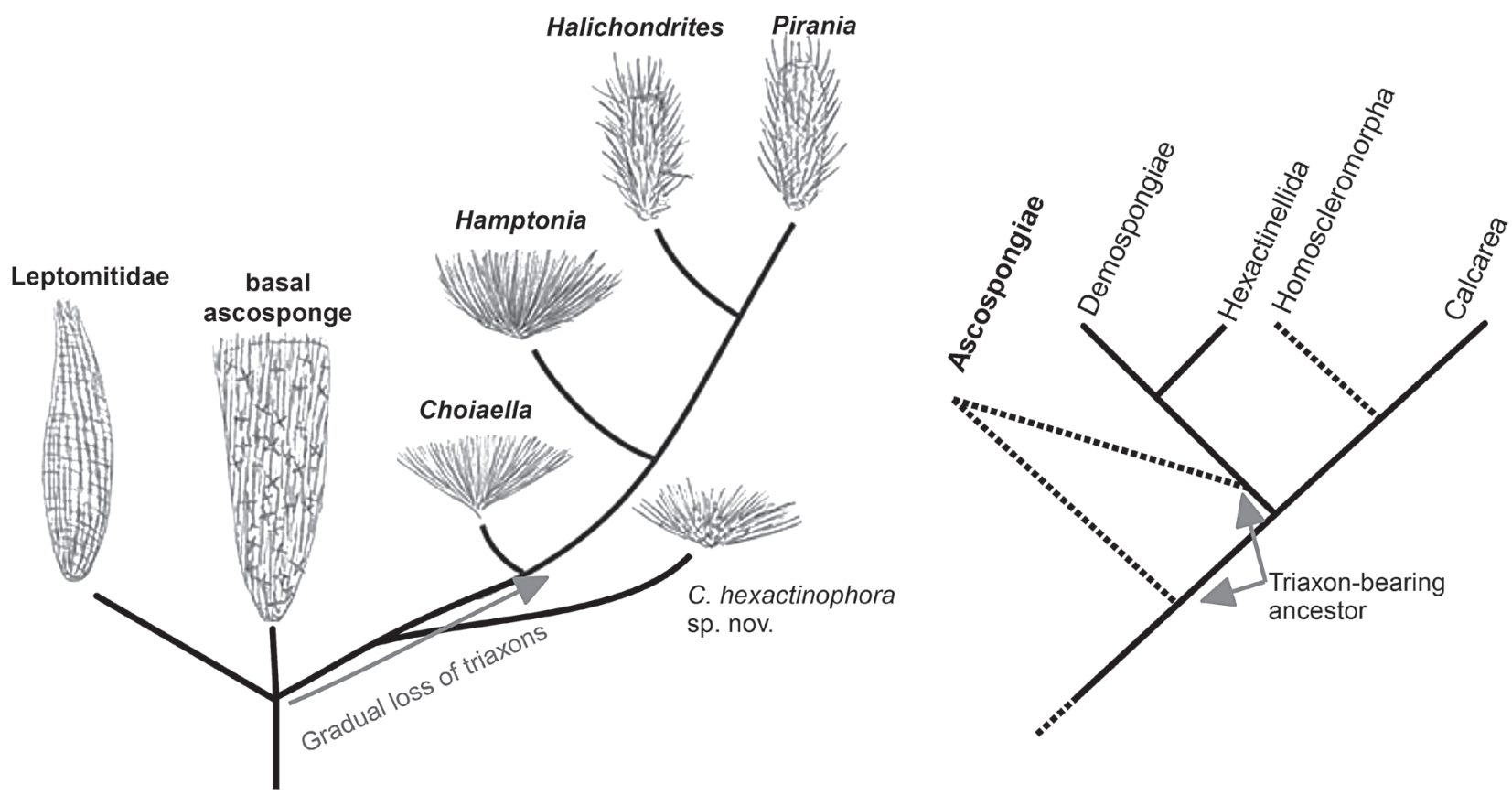

Figure 5. Evolutionary interpretation of the Ascospongiae nov. (modified after Botting et al. 2013), showing position of Choiaella hexactinophora sp. nov. as an intermediate stage, and interpretation of the placement of the Ascospongiae relative to the extant classes, as sister group to the rest of the Porifera or Silicea. 
demosponges. There are other preservable physical differences between spicules in these two extant classes, but these differences also break down in the fossil record (e.g. hexagonal filament symmetry in a hexactin-bearing reticulosan sponge; Botting \& Muir 2013). Hexactins in early members of the group such as Choiaella are fully consistent with (and predicted by) the evolutionary scenario of Botting \& Muir (2018), but other nontraditional alternatives must also be considered.

One conceivable interpretation is that the protomonaxonids are aberrant hexactinellids (de Laubenfels 1955, 1958; Reitner \& Mehl 1996; Debrenne \& Reitner 2001). Some extant rossellids have a diactin-dominated skeleton (Tabachnick 2002), even though they retain some triaxons in some skeletal layers (e.g. gastralia), so loss of hexactins through the lineage would be unlikely, but not impossible. Other palaeontological evidence, however, effectively eliminates this possibility, in that there are radical differences in body morphology, skeletal architecture, and also mineralogy. The only case in which original mineralogy of spicules has been confirmed in ascosponges is in the biminerallic (silica core plus probably carbonate outer layer) spicules of Lenica (Botting et al. 2012), with the original mineralogy of other protomonaxonid taxa effectively unknown due to taphonomic overprinting. In many taxa, however, there is a thick organic outer lamina; this includes Lenica where in some cases the largest spicules are clearly compressed (showing brittle fracture), especially towards their bases where biomineralisation was thinnest (Botting \& Peel 2016). The organic exterior is also a major structural component of the spicules in Pirania, in which the spicules are visibly twisted in some specimens (Botting et al. 2013, fig. 4.5). These observations of both taxa require a radical departure from hexactinellid (or any other extant) spicule construction.

Morphologically, the ascosponges show some similarities to the reticulosans (stem-group hexactinellids, according to Finks et al. 2004, or a paraphyletic ancestral grouping according to Botting \& Muir 2018), in having a thin skeletal wall and (in the leptomitids) some degree of reticulation through the addition of transverse spicules. However, the dominant skeletal fabric is longitudinal or plumose (rather than reticulate) in protomonaxonids, often with a twisted, diagonal orientation that is most visible in basal groups (Walcott 1920, Rigby \& Collins 2004, Botting et al. 2013). This type of skeletal fabric is present in the leptomitids, which are the group most closely compared with hexactinellids by de Laubenfels (1955). Crown-group hexactinellids of both extant subclassess (Hexasterophora and Amphidiscophora) are much more complex in construction (Reiswig 2006, Dohrmann et al. 2017). Their spicule skeleton contains multiple skeletal layers (dermal, choanosomal, gastral) each with modified spicule morphologies (based on the hexactine template), and complex arrangement of spicules within each layer. The simplest skeletal architectures are those in which the skeleton is fused into a solid framework, which has allowed them to dispense with more complex internal support organisation. Overall, hexactinellid morphology entirely contradicts the simple, constrained structure of ascosponges. If ascosponges are to be fitted into hexactinellid evolution, then they must have diverged greatly from their common ancestor with living forms, including adoption of different materials to construct the spicules, in different forms, and with a different skeletal arrangement. These features would all need to have been incorporated into an extremely simplified, thin-walled body form, with no evidence for any intermediate stages.

The only reason to place the ascosponges into the Hexactinellida would be the presence of hexactins, but these are also known among fossils in heteractinid calcareans such as Eiffelia (Botting \& Butterfield 2005) and in the entirely calcitic reticulosan-like sponge Carduispongia (Nadhira et al. 2019) that shows calcarean-like soft tissue structure. Hexactins are also present in the proposed stemgroup demosponges Cyathophycus loydelli Botting, 2004 and Conciliospongia (Botting et al. 2017). Therefore, there is no support for speculating that hexactins are an autapomorphy of Hexactinellida; rather, they have been lost in demosponges, and independently in calcareans/ homoscleromorphs.

Assignment of the ascosponges to the calcareans is even less plausible than to extant siliceans (hexactinellids and demosponges), even though some calcareans have an asconoid aquiferous system. (Such asconoid organisation is plasuible for the Ascospongiae, given the absence of any evidence for chambers, canals or other cavities in the very thin body wall, but it remains possible that an alternative type of organisation existed, such as isolated microscopic chambers that all exit to the interior individually; this cannot be resolved from current fossil material.) Calcarean spicules are minute, entirely calcitic, and formed as monaxons, triactins or tetractins. There is a wide range of body form and structure, but many sponges are very small, and their internal architecture appears to have been highly prone to convergence (Manuel et al. 2003). Even in the simplest morphologies, such as those of Leucosolenia (e.g. Chu et al. 2020), there is little morphological similarity to the ascosponges, even ignoring the most derived and anomalous traits of the group. The similarities that are present (radial symmetry and simple, probably ascon aquiferous system) are highly likely to be plesiomorphic.

The Homoscleromorpha (Gazave et al. 2011) are even more distinct, being entirely encrusting, amorphous sponges that have either no skeleton at all, or one of minute tetractins. Their relationship to other sponges remains somewhat unclear, and their morphology appears to be highly specialised. 
The relationship of the Ascospongiae to the extant classes (Fig. 5) remains unclear, but a sister-group relationship to either Silicea or Porifera is plausible. The presence of biminerallic, organic-sheathed spicules in the group most parsimoniously implies structural continuity of spicules with that of the last common ancestor of Porifera. Among the potential early-branching groups, the calcarean lineage is represented by heteractinids (Botting \& Butterfield 2015) and shows hexactins but almost no indication of diactins. The body form of early heteractinids such as Eiffelia is globose rather than conical, and no additional similarities are seen with the calcareous 'reticulosan' Carduispongia that may represent a different part of the calcarean stem group (Nadhira et al. 2019). Similarities to late stem-group Silicea are also relatively few, as these are best represented by the reticulosans like Cyathophycus (Botting \& Muir 2013, 2018; Botting et al. 2017) that show a regularly reticulate primary skeleton with additional internal layers. Simpler taxa such as Heminectere Botting, 2004 retain the triaxon-based, orthogonal skeleton and lack diactins; anchoring seems to have been achieved through short extensions of the basal triaxons (Botting 2004).

The only fossil taxon that is structurally similar to ascosponges within the spectrum of early sponge fossils is Diagoniella Rauff, 1894 (e.g. Rigby 1978, Caron et al. 2010), as discussed by Botting \& Muir (2018). The combination of a diagonally oriented skeleton (dominantly of stauractins) with longitudinal diactins that act as anchoring spicules provides at least a superficial point of comparison. The relationship of Diagoniella to the tetraradially symmetric takakkawiids (interpreted by Botting \& Muir 2018 as the early stem group of Porifera) requires more information for clarification, but points of similarity include the body form, spicule morphology, and generally diagonal arrangement of the spicules in the primary skeletal wall panels of Metaxyspongia and allies (Wu et al. 2005, Botting et al. 2014). At this stage, placement as sister-group to the extant Porifera is best supported, but the evidence remains inconclusive.

\section{Conclusions}

A new species of Choiaella is described from the Middle Ordovician of Wales that possesses hexactine spicules, confirming a previous report from a private collection of hexactins in a choiid from the Lower Ordovician of Morocco. This finding supports the continuity of their problematic lineage (Group 1 protomonaxonids of Botting et al. 2013), from tall, thin-walled basal members to the flatter, discoidal, conical or bowl-shaped taxa such as Choia and Hamptonia. As this finding effectively rules out a demosponge affinity for even part of the group, and other features make a close relationship to hexactinellids highly implausible, the implication of this information is that mineralised spicules were shared across at least some classes, as argued by Botting \& Muir (2018). This conclusion suggests that Tang et al.'s (2019) and Murdock's (2020) hypothesis of early sponges having largely unpreservable, organic spicules, cannot be applied across the crown group of the phylum.

In order to accommodate this group, formerly known as protomonaxonids (but with an unusable definition and polyphyletic content), I erect the new class Ascospongiae.

\section{Acknowledgements}

The microscopes used in this study were purchased through crowdfunding, and all donors are gratefully acknowledged; this includes a Holloway Bursary from the Warwickshire Geological Conservation Group. Members of the Mid Wales Palaeontology Group have assisted on fieldwork, and site access was supported by Ben Douel and family. Thanks also to Lucy Muir for constructive comments on the manuscript, Radek Vodrážka and an anonymous referee for thoughtful reviews, and Olda Fatka as the handling editor.

\section{References}

Beresi, M.S., Botting, J.P. \& Clarkson, E. 2010. A new demosponge, Choiaella scotica, from the Caradoc (Ordovician) of Wallace's Cast, Southern Uplands. Scottish Journal of Geology 46, 77-83.

DOI 10.1144/0036-9276/01-387

Botтing, J.P. 2004. An exceptional Caradoc sponge fauna from the Llanfawr Quarries, central Wales and phylogenetic implications. Journal of Systematic Palaeontology 2, 31-63. DOI 10.1017/S147720190300110X

Botting, J.P. 2016. Diversity and ecology of sponges in the Early Ordovician Fezouata Biota, Morocco. Palaeogeography, Palaeoclimatology, Palaeoecology 460, 75-86.

DOI 10.1016/j.palaeo.2016.05.018

Botting, J.P. \& Butterfield, N.J. 2005. Reconstructing early sponge relationships by using the Burgess Shale fossil Eiffelia globosa, Walcott. Proceedings of the National Academy of Sciences of the United States of America 102, 1554-1559. DOI 10.1073/pnas.0405867102

Botting, J.P. \& Muir, L.A. 2008. Unravelling causal components of the Ordovician Radiation: the Builth Inlier (central Wales) as a case study. Lethaia $41,111-125$. DOI 10.1111/j.1502-3931.2008.00118.x

Botting, J.P. \& Muir, L.A. 2013. Fauna and ecology of the holothurian bed, Llandrindod, Wales, UK (Darriwilian, Middle Ordovician), and the oldest articulated holothurian. Palaeontologia Electronica 15.1.9A, 1-28. DOI 10.26879/272

Botting, J.P. \& Muir, L.A. 2018. Early sponge evolution: 
a review and phylogenetic framework. Palaeoworld 27, 1-29. DOI 10.1016/j.palwor.2017.07.001

Botting, J.P. \& Peel, J.S. 2016. Early Cambrian sponges of the Sirius Passet Biota, North Greenland. Papers in Palaeontology 2, 463-487. DOI 10.1002/spp2.1048

BotTing, J.P. \& Zhang, Y. 2013. A new leptomitid-like sponge from the Early Ordovician of China with heteractinid spicules. Bulletin of Geosciences 88, 207-217.

DOI 10.3140/bull.geosci.1361

Botting, J.P., Muir, L.A., Sutton, M.D. \& Barnie, T. 2011. Welsh gold: A new exceptionally preserved pyritized Ordovician biota. Geology 39(9), 879-882. DOI 10.1130/G32143.1

Botting, J.P., Muir, L.A., XiaO, S., Li, X. \& Lin, J.P. 2012. Evidence for spicule homology in calcareous and siliceous sponges: biminerallic spicules in Lenica sp. from the Early Cambrian of South China. Lethaia 45, 463-475. DOI 10.1111/j.1502-3931.2012.00308.x

Botting, J.P., Muir, L.A. \& Lin, J.P. 2013. Relationships of the Cambrian Protomonaxonida (Porifera). Palaeontologia Electronica, 16.2.9A, 1-23. DOI 10.26879/339

Botting, J.P., YuAn, X. \& Lin, J.P. 2014. Tetraradial symmetry in early poriferans. Chinese Science Bulletin 59, 639-644. DOI 10.1007/s11434-013-0099-Z

Botting, J.P., Zhang, Y.D. \& Muir, L.A. 2017. Discovery of missing link between demosponges and hexactinellids confirms palaeontological model of sponge evolution. Scientific Reports 7(5286), 1-7. DOI 10.1038/s41598-017-05604-6

Botting, J.P., Stewart, S.E., Muir, L.A. \& Zhang, Y. 2019. Taxonomy and evolution of the protomonaxonid sponge family Piraniidae. Palaeontologia Electronica 22.3.76, 1-27. DOI 10.26879/998

Caron, J.B., Gaines, R.R., Mángano, M.G., Streng, M. \& Daley, A.C. 2010. A new Burgess Shale-type assemblage from the "thin" Stephen Formation of the southern Canadian Rockies. Geology 38, 811-814. DOI 10.1130/G31080.1

Chu, Y., Gong, L. \& LI, X. 2020. Leucosolenia qingdaoensis sp. nov. (Porifera, Calcarea, Calcaronea, Leucosolenida, Leucosoleniidae), a new species from China. ZooKeys 906, 1-11. DOI 10.3897/zookeys.906.47164

Clites, E.C., Droser, M.L. \& Gehling, J.G. 2012. The advent of hard-part structural support among the Ediacara biota: Ediacaran harbinger of a Cambrian mode of body construction. Geology 40, 307-310. DOI 10.1130/G32828.1

Cong, P.Y., Harvey, T.H., Williams, M., Siveter, D.J., Siveter, D.J., Gabвотt, S.E., Li, Y.J., Wei, F. \& Hou, X.G. 2018. Naked chancelloriids from the lower Cambrian of China show evidence for sponge-type growth. Proceedings of the Royal Society B: Biological Sciences 285, 20180296, 7 pp. DOI 10.1098/rspb.2018.0296

Cunningham, J.A., Liu, A.G., Bengtson, S. \& Donoghue, P.C. 2017. The origin of animals: can molecular clocks and the fossil record be reconciled? BioEssays 39, 1-12. DOI 10.1002/bies.201600120

Davies, J.R., Fletcher, C.J.N., Waters, R.A. \& Wilson, D. 1997. Geology of the country around Llanilar and Rhayader: memoir for 1: 50000 geological sheets 178 and 179 (England and Wales). Memoir (Sheet) British Geological Survey 178. 284 pp. HM Stationery Office, London.

Debrenne, F. \& Reitner, J. 2001. Sponges, cnidarians, and ctenophores, 301-325. In Zhuravlev, A. Yu. \& Riding, R. (eds) The ecology of the Cambrian radiation. Columbia University Press, New York.

DOI 10.7312/zhur10612-014

de Laubenfels, M.W. 1955. Porifera, E21-E112. Treatise on Invertebrate Paleontology. Part. E. Geological Society of America and University of Kansas Press, Lawrence.

DE Laubenfels, M.W. 1958. Nomenclature of Porifera, especially concerning the so-called "Glass Sponges" or Hyalospongea. Journal of Paleontology 32, 611-616.

Dohrmann, M. \& Wörheide, G. 2017. Dating early animal evolution using phylogenomic data. Scientific Reports 7, 1-6. DOI 10.1038/s41598-017-03791-w

Dohrmann, M., Kelley, C., Kelly, M., Pisera, A., Hooper, J.N.A. \& Reiswig, H.M. 2017. An integrative systematic framework helps to reconstruct skeletal evolution of glass sponges (Porifera, Hexactinellida). Frontiers in Zoology 14(18), 1-31. DOI 10.1186/s12983-017-0191-3

DzIK, J. 2002. Early diversification of organisms in the fossil record, 219-48. In Palya, G., Zucchi, C. \& Caglioti, L. (eds) Fundamentals of Life. Elsevier Science S.A., Paris.

FinKs, R.M. \& RigbY, J.K. 2004. Paleozoic Demosponges, 9-171. In Finks, R.M., Reid, R.E.H. \& Rigby, J.K. (eds) Treatise on Invertebrate Paleontology, Part E, Porifera, Revised, Volume 3. Geological Society of America and University of Kansas Press, Boulder, Colorado \& Lawrence, Kansas.

Finks, R.M., Reid, R.E.H. \& Rigby, J.K., 2004. Treatise on Invertebrate Paleontology, Part E, Porifera, Vol. 3, Revised, $872 \mathrm{pp}$. Geological Society of America and University of Kansas Press, Boulder, Colorado, and Lawrence, Kansas.

García-Bellido, D.C., Gozalo, R., Chirivella Martorell, J.B. \& Linan, E. 2007. The demosponge genus Leptomitus and a new species from the Middle Cambrian of Spain. Palaeontology 50, 467-478.

DOI 10.1111/j.1475-4983.2007.00635.x

Gazave, E., Lapébie, P., Ereskovsky, A.V., Vacelet, J., Renard, E., CÁrdenas, P. \& Borchiellini, C. 2011. No longer Demospongiae: Homoscleromorpha formal nomination as a fourth class of Porifera, 3-10. In Maldonado, M., Turon, X., Becerro, M.A. \& Jesús Uriz, M. (eds) Ancient Animals, New Challenges. Springer, Dordrecht.

DOI 10.1007/978-94-007-4688-6_2

GoryanskiI, V.Yu. 1977. Pervaya nakhodka ostatkov gubki v nizhnem kembrii Vostochnoi Sibiri [First discovery of sponge remains from the Lower Cambrian in eastern Siberia]. Ezhdegod-nik vsesoyuznogo paleontologicheskogo obschestva 20, 274-278. [in Russian]

Grant, R.E. 1836. Animal kingdom, 107-118. In Todd, R.B. (ed.) The cyclopedia of anatomy and physiology, vol. 1 . Sherwood, Gilbert and Piper, London.

GraY, J.E. 1867. Notes on the arrangement of sponges, with the description of some new genera. Proceedings of the Zoological Society of London 1867, 492-558. 
Jell, P.A. \& Cook, A.G. 2011. Musaspongia amnicola, a new sponge from the Lower Devonian of Victoria. Proceedings of the Royal Society of Victoria 123, 138-142.

Keupp, H. \& Schweigert, G. 2012. Neochoiaella n. gen. (Demospongeae, Choiaellidae)—a second poriferan Lazarus taxon from the Solnhofen Plattenkalk (Upper Jurassic, Southern Germany)? Paläontologische Zeitschrift 86, 269-274. DOI 10.1007/s12542-012-0134-4

LÉvi, C. 1956. Étude de Halisarca de Roscoff. Embryology et systématique des Démosponges. Archives de Zoologie Expérimentale et Générale 93, 1-181.

Manuel, M., Borchiellini, C., Alivon, E., Le Parco, Y., Vacelet, J. \& Boury-Esnault, N. 2003. Phylogeny and evolution of calcareous sponges: monophyly of Calcinea and Calcaronea, high level of morphological homoplasy, and the primitive nature of axial symmetry. Systematic Biology 52, 311-333. DOI 10.1080/10635150390196966

Muir, L.A. \& Botting, J.P. 2015. An outline of the distribution and diversity of Porifera in the Ordovician Builth Inlier (Wales, UK). Palaeoworld 24, 176-190.

DOI 10.1016/j.palwor.2014.11.003

Murdock, D.J. 2020. The 'biomineralization toolkit' and the origin of animal skeletons. Biological Reviews 95, 1372-1392. DOI 10.1111/brv. 12614

Nadhira, A., Sutton, M.D., Botting, J.P., Muir, L.A., Gueriau, P., King, A., Briggs, D.E., Siveter, D.J. \& Siveter, D.J. 2019. Three-dimensionally preserved soft tissues and calcareous hexactins in a Silurian sponge: implications for early sponge evolution. Royal Society Open Science 6(7), 190911, 7 pp. DOI 10.1098/rsos.190911

Nettersheim, B.J., Brocks, J.J., Schwelm, A., Hope, J.M., Not, F., Lomas, M., Schmidt, C., Schiebel, R., Nowack, E.C., De Deckker, P. \& Pawlowski, J. 2019. Putative sponge biomarkers in unicellular Rhizaria question an early rise of animals. Nature Ecology \& Evolution 3(4), 577-581. DOI 10.1038/s41559-019-0806-5

Rauff, H. 1894, Palaeospongiologie. Palaeontographica 40, 233-346 pp, $17 \mathrm{pl}$.

Reiswig, H.M. 2006. Classification and phylogeny of Hexactinellida (Porifera). Canadian Journal of Zoology 84, 195-204. DOI 10.1139/z05-174

Reitner, J. \& Wörheide, G. 2002. Non-lithistid fossil Demospongiae-origins of their palaeobiodiversity and highlights in history of preservation, 52-70. In HoOPER, J.N.A. \& Van Soest, R.M.W. (eds) Systema Porifera: A Guide to the Classification of Sponges. Kluwer Academic/Plenum Publishers, New York. DOI 10.1007/978-1-4615-0747-5_4

Reitner, J. \& Mehl, D. 1996. Monophyly of the Porifera. Verhandlungen des naturwissenschaftlichen Vereins in Hamburg $36,5-32$.

Rigby, J.K. 1978. Porifera of the Middle Cambrian Wheeler Shale, from the Wheeler Amphitheater, House Range, in western Utah. Journal of Paleontology 52, 1325-1345.

Rigby, J.K. 1986. Sponges of the Burgess Shale (Middle Cambrian), British Columbia. Palaeontographica Canadiana 2, $1-105$.
Rigby, J.K. \& Collins, D. 2004. Sponges of the Middle Cambrian Burgess and Stephen Shale Formations, British Columbia. Royal Ontario Museum Contributions in Science 1, $1-164$.

Rigby, J.K. \& Hou, X.-G. 1995. Lower Cambrian demosponges and hexactinellid sponges from Yunnan, China. Journal of Paleontology 69, 1009-1019.

DOI 10.1017/S0022336000037999

Steiner, M., Mehl, D., Reitner, J. \& Erdtmann, B.D. 1993. Oldest entirely preserved sponges and other fossils from the Lowermost Cambrian and a new facies reconstruction of the Yangtze platform (China). Berliner geowissenschaftliche Abhandlungen 9, 293-329.

TABACHNiCK, K.R. 2002. Family Rossellidae Gray, 1867, 14411505. In Hooper, J.N.A. \& VAN Soest, R.W.M. (eds) Systema Porifera: A Guide to the Classification of Sponges. Kluwer Academic/Plenum Publishers, New York. DOI 10.1007/978-1-4615-0747-5 148

Tang, Q., Wan, B., Yuan, X., Muscente, A.D. \& Xiao, S. 2019. Spiculogenesis and biomineralization in early sponge animals. Nature Communications 10(3348), 1-10. DOI 10.1038/s41467-019-11297-4

VAN Soest, R.W. \& Hooper, J.N., 2002. Order Halichondrida Gray, 1867, 721-723. In Hooper, J.N.A. \& VAN Soest, R.W.M. (eds) Systema Porifera: A Guide to the Classification of Sponges. Kluwer Academic/Plenum Publishers, New York. DOI 10.1007/978-1-4615-0747-5_79

Walcott, C.D. 1920. Middle Cambrian Spongiae. Cambrian geology and paleontology IV. Smithsonian Miscellaneous Collections 67, 261-364.

Wang, Q.J., Peng, J., Wen, R.Q., Du, G.Y., Zhang, H., Wang, D.Z. \& WANG, Y.F. 2019. Hamptonia jianhensis sp. nov. from the Cambrian (Stage 4) Balang Fauna of Guizhou, China. Historical Biology 32, 1-9. DOI 10.1080/08912963.2019.1575374

Wu, W., Yang, A., Janussen, D., Steiner, M. \& Zhu, M. 2005. Hexactinellid sponges from the Early Cambrian black shale of South Anhui, China. Journal of Paleontology 79, 1043-1051. DOI 10.1666/0022-3360(2005)079[1043:HSFTEC]2.0.CO;2

Wu, W., Zhu, M. \& Steiner, M. 2014. Composition and tiering of the Cambrian sponge communities. Palaeogeography, Palaeoclimatology, Palaeoecology 398, 86-96. DOI 10.1016/j.palaeo.2013.08.003

YAnG, X., Zhao Y. \& Wu, W. 2003. Discovery of the Early and Middle Cambrian Choiidae from Guizhou, SW China. Acta Micropalaeontologica Sinica 21, 286-295.

Zong, R.W., Liu, Q., WeI, F. \& Gong, Y.M. 2017. Fentou Biota: a Llandovery (Silurian) shallow-water exceptionally preserved biota from Wuhan, Central China. The Journal of Geology 125, 469-478. DOI 10.1086/692331

Zumberge, J.A., Love, G.D., CÁrdenas, P., Sperling, E.A., Gunasekera, S., Rohrssen, M., Grosjean, E., Grotzinger, J.P. \& Summons, R.E. 2018. Demosponge steroid biomarker 26-methylstigmastane provides evidence for Neoproterozoic animals. Nature Ecology \& Evolution 2, 1709-1714.

DOI 10.1038/s41559-018-0676-2 